\title{
SYNTHESIS OF ARTS IN THE UKRAINIAN ARCHITECTURE OF THE 1960-1980S AND 2010s: COMMON FEATURES AND DIFFERENCES
}

\author{
Liudmila Bachinska, PhD of architecture, professor \\ Ukraine, Kyiv, Kyiv National University of Construction and Architecture \\ Department of Fundamentals of Architecture and Architectural Design
}

DOI: https://doi.org/10.31435/rsglobal_ws/12072018/6010

\section{ARTICLE INFO}

Received: 20 May 2018

Accepted: 15 June 2018

Published: 12 July 2018

\section{KEYWORDS}

influence of the political regime;

Soviet power;

Independent Ukraine;

synthesis of arts in architecture;

mosaics and murals.

\begin{abstract}
The article deals with two periods of the formation of monumental art in the Soviet (1960-1980s) and Independent Ukraine (2010-ies). A comparison of the consequences of the formation of the architectural and spatial organization of the urban environment in both periods has been made and their specificity in each period is substantiated by differences in the purpose of their application: in Soviet times, this is the embodiment of state-ideological tasks, in the time of Independence of Ukraine this is a reflection of social expectations.
\end{abstract}

Citation: Liudmila Bachinska. (2018) Synthesis of Arts in the Ukrainian Architecture of the 1960-1980s and 2010s: Common Features and Differences. World Science. 7(35), Vol.2. doi: 10.31435/rsglobal_ws/12072018/6010

Copyright: (C) 2018 Liudmila Bachinska. This is an open-access article distributed under the terms of the Creative Commons Attribution License (CC BY). The use, distribution or reproduction in other forums is permitted, provided the original author(s) or licensor are credited and that the original publication in this journal is cited, in accordance with accepted academic practice. No use, distribution or reproduction is permitted which does not comply with these terms.

Introduction. In the history of peoples who lived from ancient times in the territory of modern Ukraine, an important part of their life was the ways of knowing themselves, their surroundings, their lives, family relationships, communication as ways of self-identification and expression through figurative means. In households, clothes, homes, all this was reflected with the help of conditional drawings, forms were made in clay or carved out of wood, which were bearers of some clearly defined information such as the story of life events and protection. People used such signs as a peculiar language, which eventually began to acquire aesthetic and symbolic properties $[3,5,11,18]$. In Fig. 1, $a-b$, examples of painting of the house and dishes of Trypillians are given.

In the following, among many different forms of self-expression, the painting of walls spread, which eventually took shape in two main directions, both folk and state art. The last direction in connection with the spread of Byzantine Christian culture in the territory of the state Kievan Rus became the affiliation of church building as a sign of the established statehood, as models of the most important objects of state building, where the best medieval masters of the formation of vaults, technology of construction, mosaic techniques and frescoes laid their knowledge and skills. The painting of the walls not only adorned, created a special, vivid design of the church space, but also talked about the history of Christianity, the religious essence of the Christian doctrine, and with the help of figurative means taught the people high Christian morality [15] (see Fig. 1, e-f, photo of Sophia of Kyiv - a mosaic of the Archangel Gavril and wall paintings of the interior piece).

Folk creativity in the form of murals spread in the culture of housing design, which existed almost to 90 years of the XX century in the countryside of Ukraine, until the time of the use of the latest technologies and materials borrowed from European practice. The painting of the walls helped to decorate the environment, to make it unique both externally and in the middle (see Fig. $1, c-d$ ) and to add festivity in everyday life with the help of patterns and colours made by the mistress- proprietress [8, 17, 22]. So, from ancient times, the use of the wall as an informational and artistic surface took place. 
In the history of our state in the last 60 years of existence there are two periods when the wall's figurative culture began to play a significant role in the design of the urban environment - in the times of Soviet power - 1960-1980s - and the period that began with the intervention of the Russian army in the Crimea and the Eastern regions of the Independent Ukraine. What is the common and the difference between the synthesis of wall art as a means of aesthetic design of the urban environment and the architectural shaping of these two periods?

The main content. Review of the works on the topic. The theme of the monumental legacy of the Soviet past now attracts attention $[4,9,16,18,21]$, in connection with the interest of the scientific and cultural community in Soviet history, its consequences, influences to social development, as well as in connection with the assessment of the present and comparison with the past. Already not once it was mentioned about the influence of Soviet power to culture, the formation of a specific cultural direction, that called socialist realism. The author of the article investigates the question of the full dependence of architectural and urban heritage from the political system of the USSR throughout the period of the existence of the Soviet state [1]. The theme of murals in Ukrainian territory is only born as an interesting scientific problem, the illumination of which is more likely to be given as information on the facts of the propagation of one of the areas of street-art [2, 6, 7, 10, 12-14, 20].

The purpose of the research is to find out the commonality and differences in the formation of monumental wall art that was used in the design of public spaces in Soviet times and in the Independent Ukraine. The object of research is the architecture of the two specified periods of Ukrainian history, an important information component of which is the synthesis of arts, and the subject is the features of the interaction of the architectural and spatial organization of the urban environment and objects of monumental art that arises under the influence of political regimes. The methodology of the research is based on the historical-political analysis of the situation in Ukraine, the causal link between the sociopolitical and cultural status (namely, the state of architecture and urban planning) and the comparison of the results of the architectural activities of the specialists of those periods in order to find out the reasons of appearance of specifics of the their architecture.

The political and socio-economic history of our state as a union republic within the USSR was strongly connected with the existing command system of leadership in those days in all directions of state and public life. State property was absolutely everything, the concept of private property was replaced by personal property (something that could afford a person). Totalitarianism in the system of government under the Stalin era was transformed in the mid-1950s into a one-party leadership headed by the party's general secretary. The so-called Soviet system of governance, based on the supposedly hierarchy of councils of people's deputies, was in fact completely subdued by the party nomenclature, which also covered the legislative and executive branch of government.

By the beginning of the 1950s, Stalin's Empire was dominant in Soviet architecture as a way of expressing totalitarianism, which was characterized by the erection of majestic city-centred ensembles with axial symmetry, sculptural compositions, massive state and social symbols. What happened in the future? Why gave up pseudo-empire forms that was typical of the times of the domination of dictators?

The economy of one state is strongly linked to the world economic system and is conditioned by the dynamics of its development; the policy of one state depends on the political actions of other states. The whole world exists in a single system of interconnections and interactions. The Soviet Union began a new direction in politics in the international arena and chose new landmarks in the country's economy. The state began to actively work to create a world socialist camp, to engage with the financial support of the Far and Near East, Africa and Latin America, spreading its influence to the politics, economy and culture of these countries, including to their architecture. The integration processes have begun, which led not only to one-sided influence, but also to cultural borrowings, including directions in architecture. In comparison with the previous period, architecture has lost a lot of layers, complexity of forms, verbosity due to extraordinary decoration by socio-political content. 


\section{FOLK ARCHITECTURE OF UKRAINE}
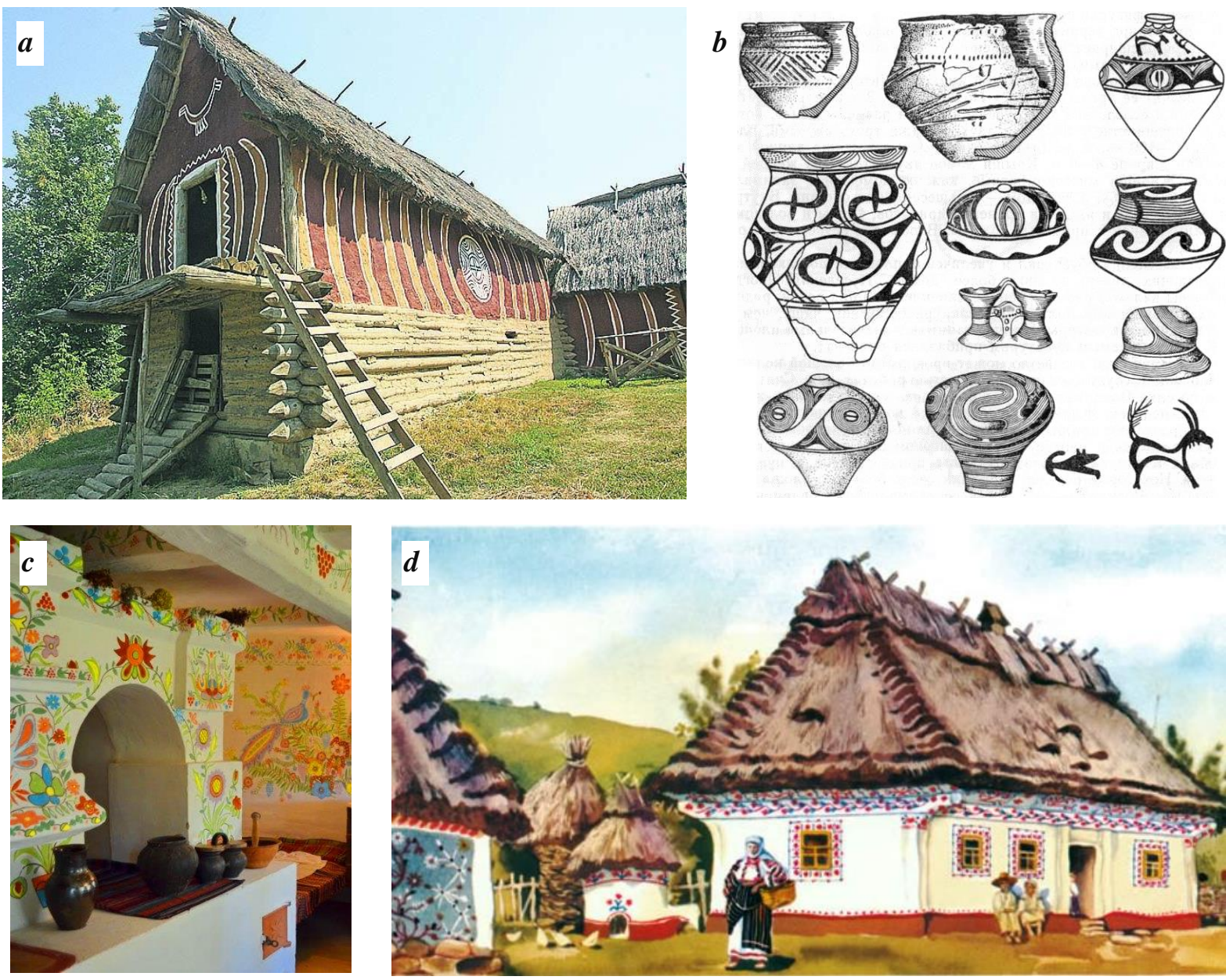

\section{STATE ARCHITECTURE OF UKRAINE}
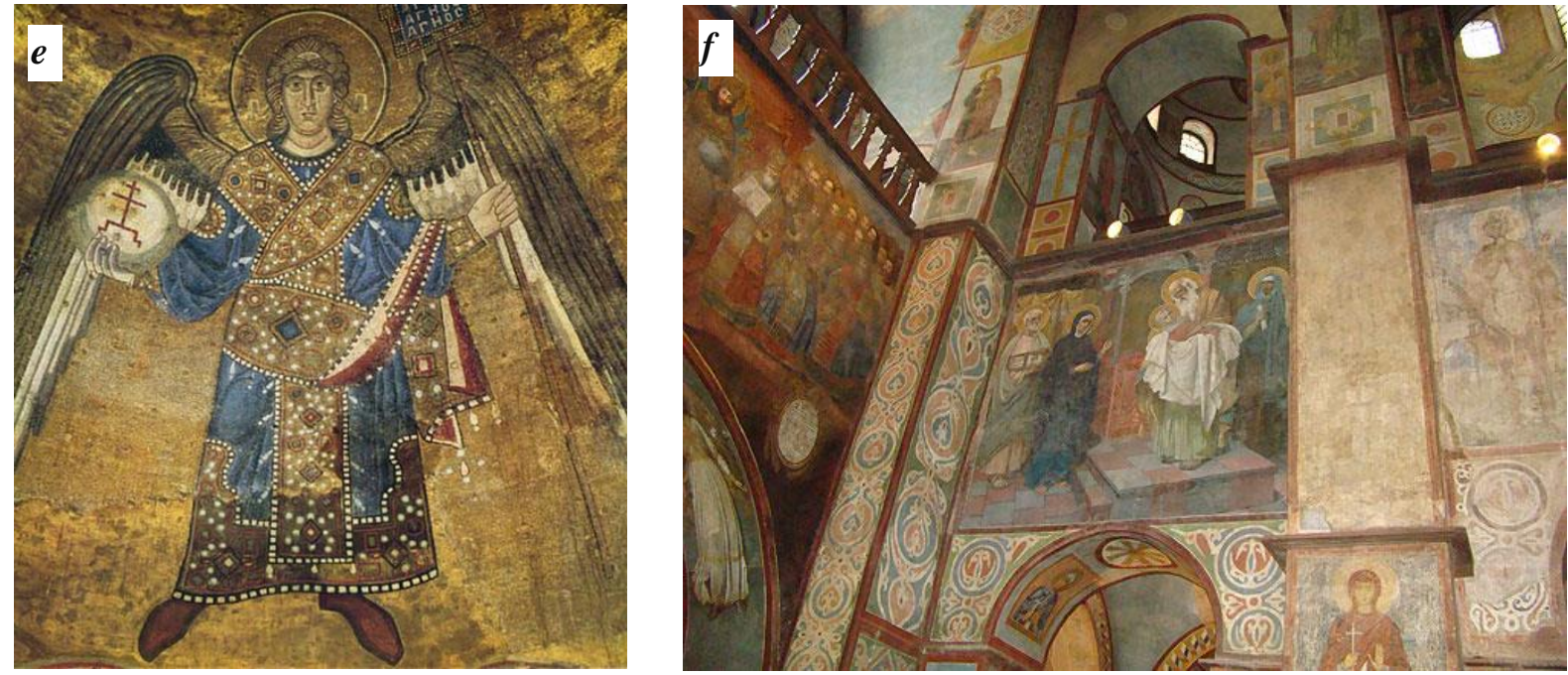

Fig. 1. - Paintings of buildings on the territory of Ukraine: a - Trypillya culture - two-story building [5]; $b$ - dishes of Trypillians, 6000 BC to RH. [11]; $c$ and $d$ - the interior of the ancient Ukrainian hut and the yard of Podillya, the end of the XIX and early XX centuries. [17]; $e$ - a mosaic of the arch of St. Sophia of Kyiv, Archangel Gabriel, and f-a fragment of the interior of Sophia of Kyiv, the beginning of the XII century [15]. 
Architecture became geometrically simple according to the world experience of the time, more humane, lost the old techniques of decorative design and acquired the new ones that were necessary for the proclamation of the formerly tested by the Soviet system of the ideological thesis - the strength, reliability and invincibility of the then existing political regime, social advantages the socialist system of economic management, which will inevitably lead to the construction of a bright future for the working masses. It is precisely these theses that became the main theme of figurative means in architecture of the 1960-1980's, which was supposed to introduce them into public consciousness, in order to embody the dominant state ideology in it. The state financed expensive materials, labor-intensive technology, and large funds for labor remuneration of artists-members of controlled creative unions, charged with executing orders in accordance with the ideological guidelines of the Communist Party as the only governing body. Therefore Soviet architectural and spatial organization of cities differed from the European urban environment, that the authorities used the means of fine arts to propagate Soviet reality and the Soviet way of life. The most widespread among various types of monumental art was a mosaic - bright, beautiful, created for the age, even mosaic-sculptural compositions, which were always placed in the most important places of visual perception of the environment as the carriers of the main information. Mosaics glorified the workers 'and peasants' state, the Soviet power, the people's economy, the army, technology, the culture of national minorities, the friendship of the peoples of the USSR and other countries of the socialist camp, the labor professions, labor, the health of the nation, the physical development of the Soviet man, and others like that. The state and social content of thematic mosaics served as an advocate for the role of the former Stalin era of plastic arts in shaping the urban space, which was an instrument of state-ideological pressure to the public consciousness.

Coordinator of the project «Soviet Mosaics of Ukraine» Eugenia Molar says that the history of mosaics began in the mid-1950s, when in the USSR the directions in shaping the architecture were reconsidered. In parallel with the architects work by artists, especially the masters, belonging to the socalled protest art - monumentalism, worked hard. Mosaic became for them the only kind of art where they could experiment with the form. But despite this, the panels were created in harsh conditions, if the artist did not inscribe a red flag, a star or a sickle and a hammer in the panel, then he went against the system of government, and then he was waiting for the end of his career [9]. In fig. 2 it is given some examples of Soviet mosaics. They all have a mostly red color, as dominant in the compositions.

Independent Ukraine, separated from the USSR, abandoned the leading role of the Communist Party, the Soviet system of government by type of Soviet Union and totalitarian state property. Historical and political events in Ukraine since 2013 have led to a change in the public consciousness of Ukrainians. The architectural environment that propagated the benefits of the Soviet way of life, became alien, unacceptable to people. The sad events in Kyiv since late 2013 and the Russian intervention started giving birth to a new direction of monumental art in the form of street-art, the so-called «muralism» (see Fig. 3).

Why is this trend of street art - a painting of the wall - has become so popular in Ukraine? In Kiev, according to statistics, there are already more than 150 of them. Among the artists who paint on the walls of multi-storey houses, there are Ukrainians and foreigners from different countries - Australians, Britons, Argentineans, Germans, Spaniards, Americans. Mural is one of the ways of decentralizing culture; they, and in general, art in the public space, can become a real instrument of decommunization, which is very important for our society today, because of the need to get rid of the totalitarian past, but not destructively, while creating the objects of contemporary art. Mural allows you to reach a large number of people and bring over them to the problems of war, aggression, propaganda and information zombie through the means of art [2].

Analysts of CEDOS V. Podnos, I. Verbytsky, I. Tischenko, M. Gryschenko made a wonderful analysis of the role of the mural in the formation of the city's space as a symbol of the city's space identifier, a marker of the urban space, which has a symbolic load and contributes to the isolation of some elements of space from others. Urban text is a set of specific meanings, metaphors, and images available in urban space and, as a consequence, associated with this city. He acts simultaneously agent (that is, creates an objective image of the city), and a structuring measure of urban space (constructs certain practices, ideas, norms of stay in the city). Part of this text is murals. Accordingly, the important functions of the murals, in addition to the declared revitalization and enhancement of attractiveness, are: the creation of new spatial landmarks; constructing of space (murals become new to space objects, but also create their own «metaspace», breaking or changing traditional spatial dispositions); marking the space - introducing new and important character markers, through which the space becomes symbolically colored. That is, murals are considered as an exclusively positive spatial change [20].

Comparison of the Soviet mosaics of the 1960s-1980s and the murals of the 2010s of Independent Ukraine on organizational and financial issues, the theme of the use of works of monumental art and figurative means to reveal the theme, as well as the purpose of creating of works of art are given in the Table 1. 
Following the consideration of both artistic trends, we can draw the following conclusions:

1. Common in both directions of wall art is the fact that Soviet mosaics and murals of the Independent Ukraine are information on a certain theme, content and form, which with the help of figurative means paintings, compositions, inscriptions, colors - provides the strongest influence to the senses of people.

\section{MOSAICS OF THE SOVIET UKRAINE 1960 - 1980-th YEARS}
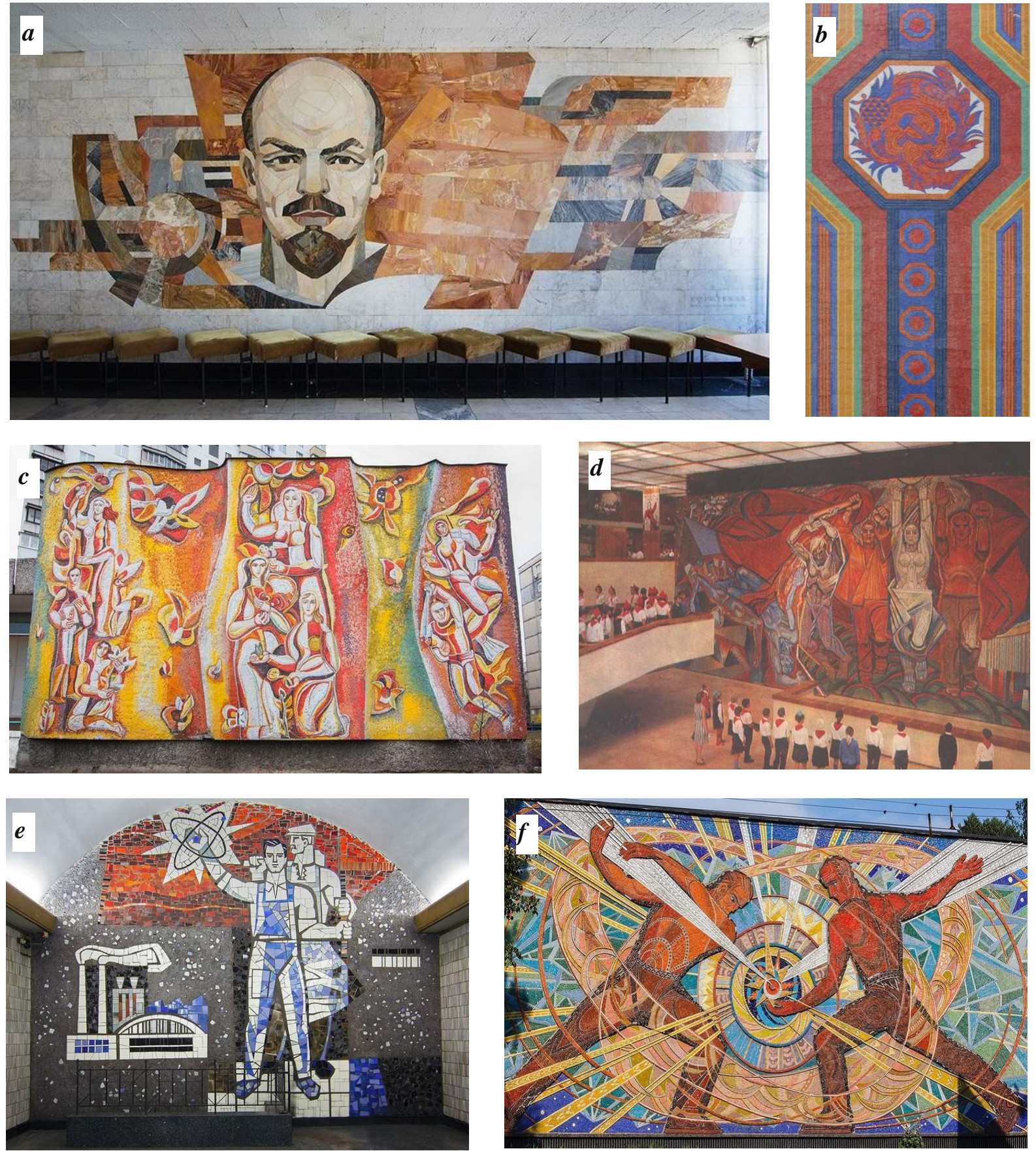

Fig. 2 - Mosaic of Soviet Ukraine: a - photo by E. Nikiforov [18]; $b$ - decorative panel «UkrSSR», aut. I. Litovchenko, V. Pryadka, 1980s, pros. Peremoha, № 25 [18]; c - mosaic «Environmental protection», 1975, st. Malyshka, № 25, Kyiv; $d$ - Soviet mosaic on facades and in interiors of children's institutions; $e$ - panels in the interior of the metro «Bolshevik» (now - «Shuliavka»), Kyiv, aut. I. Litovchenko, 1963, pros. Peremoha, 1967-1968, ceramic mosaic, colored cements, aut. photo - E. Nikiforov [16]; f- «Blacksmith of the present», aut. G. Zubchenko and G. Pryshedko, Institute for Nuclear Research, Pros. Nauka, Kyiv [4]. 


\section{MURALS OF INDEPENDENT UKRAINE 2010s YEARS}
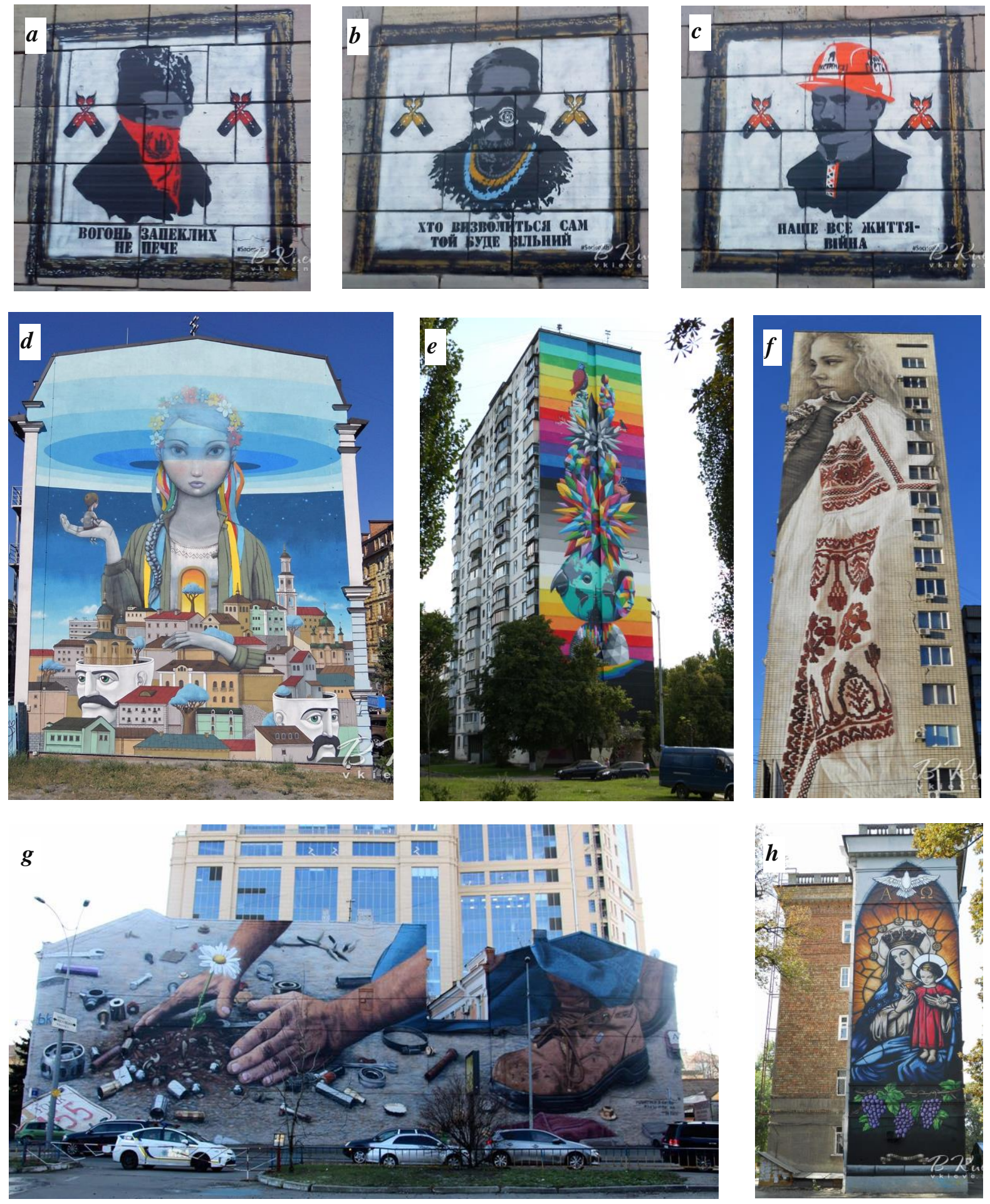

Fig. 3 - Murals of Kiev during the Russian intervention in Ukraine: $a-c-$-Icons of the Revolution», st. Hrushevsky, 4, 10.02.2014, aut. \#Sociopath, Kyiv [7]; d-«Revival», str. Borichiv

Tik, 33 / 6a, 2014, Kyiv, aut. O. Kislov (Ukraine), J. Mallan (France - «Seth») [13];

$e-«$ Volya», Akademgorodok, Blvd. Vernadsky, 87, 2015, Kyiv, aut. Oscar San Miguel Erica (Spain) [2]; $f$ - «Dedication to women of Ukraine», Blvd. Lesia Ukrainka, 36a, Kyiv, aut. Guido Van Helten, photo of Geo Leros [6]; $g$ - «Get up from the dirt», building of the police of Pechersk district, Kyiv, str. Moscow, 30, 2017, aut. BKfoxx (USA) [12]; 
Table 1. A comparative analysis of the objects of the synthesis of arts in the architecture of the 1970-1980's and 2010's

\begin{tabular}{|c|c|c|}
\hline $\begin{array}{l}\text { Objects of comparative } \\
\text { analysis }\end{array}$ & $\begin{array}{l}\text { Mosaic panels in the architecture } \\
\text { of Soviet Ukraine }\end{array}$ & $\begin{array}{l}\text { Muralism in the architecture of } \\
\text { the Independent Ukraine }\end{array}$ \\
\hline $\begin{array}{l}\text { Customers performing } \\
\text { works }\end{array}$ & Government order & Personal Initiative \\
\hline Order of performers & State through creative unions & No order is made \\
\hline Financing & State Financing & Works are not funded \\
\hline $\begin{array}{l}\text { The cost of performing } \\
\text { works }\end{array}$ & High paying works & $\begin{array}{l}\text { The cost of works is not } \\
\text { appreciated }\end{array}$ \\
\hline Cost of materials & Materials which cost expensive & $\begin{array}{l}\text { The artist's materials are not } \\
\text { evaluated }\end{array}$ \\
\hline Duration of performance & Long term work & Fast execution of works \\
\hline Theme of the work of art & $\begin{array}{l}\text { The glorification of Soviet power, } \\
\text { the socialist system, victories in } \\
\text { the struggle for peace, } \\
\text { collectivism, the unity of the } \\
\text { working masses and peoples in the } \\
\text { USSR, happy life in the country, } \\
\text { glorification of labor, friendship, } \\
\text { family values, health }\end{array}$ & $\begin{array}{l}\text { Hopes for the creation of a free } \\
\text { state, the worship of heroes, the } \\
\text { expectations of peace, the beauty } \\
\text { of the world, the love of nature } \\
\text { and the need for its preservation, } \\
\text { the need for spiritual purification, } \\
\text { the search for God's presence and } \\
\text { truth }\end{array}$ \\
\hline $\begin{array}{l}\text { Figurative means for the } \\
\text { disclosure of the topic }\end{array}$ & $\begin{array}{l}\text { State and social symbols, human } \\
\text { masses in a realistic or abstract- } \\
\text { realistic manner, dynamic and } \\
\text { energetic compositions, } \\
\text { predominance of red or fiery } \\
\text { colors }\end{array}$ & $\begin{array}{l}\text { Realistic-symbolic manner of } \\
\text { image, mythologization of } \\
\text { content, dynamism of } \\
\text { compositions and calmness, } \\
\text { sense of admiration, joy of } \\
\text { existence, image of a person as } \\
\text { such, personality, predominance } \\
\text { of blue color }\end{array}$ \\
\hline $\begin{array}{l}\text { The purpose of creating a } \\
\text { work of art in architecture }\end{array}$ & $\begin{array}{l}\text { Reflection in the public } \\
\text { consciousness of the role of the } \\
\text { state as the main organism, under } \\
\text { the laws of which there is a person }\end{array}$ & $\begin{array}{l}\text { The expression of the search for } \\
\text { the meaning of human life and } \\
\text { the hopes for a free and happy } \\
\text { future }\end{array}$ \\
\hline Conclusion: & $\begin{array}{l}\text { Monumental art is used as } \\
\text { propaganda of the Soviet state } \\
\text { ideology }\end{array}$ & $\begin{array}{l}\text { Street art is used as a reflection } \\
\text { of people's thoughts and hopes }\end{array}$ \\
\hline
\end{tabular}

2. The list of items indicated in the Table shows the complete opposite of both approaches to the creation of objects of art - both by purpose and by way of ordering, financing and organizing work.

3. The idea of creating an artistic product and the way of organizing its implementation on all grounds show that the creative works in the 1960s-1980s were for the state art in order to translate the state ideology into the consciousness of people, and they in 2010 are the folk art reflecting hopes of the people and his expectations in obtaining a free country with a fair system of government

\section{REFERENCES}

1. Bachinskaya Lyudmila. The development of the architectural object under the influence of social history / Underwater tecnology. Industrial and civil engineering. Vol. 6, 2017, 89-99 p. ISSN 2415-8550

2. Alena Vyshnitskaya. Mural: what is it, why and why came to our city / DIRIGIBLE. - July 12, 2016 (in Ukrainian). https://drgbl.net/shho-take-mural/

3. ANASTASIA BABCHENKO. Material and spiritual culture of Trypilly civilization /

4. I'm Correspondent. - October 14, 2013, 18:53 (in Ukrainian).

5. https://blogs.korrespondent.net/blog/users/3212945-materialna-ta-dukhovna-kultura-trypilskoi-tsyvilizatsii

6. Curator of the project «Soviet Mosaics in Ukraine» Foundation «Isolation» Evgeniya Molar explains the value of Soviet mosaics in Kiev. / Buro 24/7. CULTURE / EXPERT. Guide to invaluable Soviet mosaics of Kiev. Cultural Heritage. - 10/06/15, 17:30 (in Russian).

7. https://www.buro247.ua/culture/expert/mozaiki.html 
8. Evgeniya Pavlyukova. Ukrainians of copper age: how our ancestors lived 6000 years ago. / SIOHODNY Lifestyle / - September 10, 2014 at 15:00 (in Ukrainian).

9. https://ukr.segodnya.ua/lifestyle/fun/ukraincy-mednogo-veka-kak-zhili-nashi-predki-6000-let-nazad-548563.html

10. Girl in embroidery on Lesia Ukrainka Boulevard. Street-art / C «In Kyiv» (in Russian).

11. http://vkieve.net/street-art/devushka-v-vyshivanke-na-bulvare-lesi-ukrainki

12. «Icons of the Revolution» on Hrushevsky. Street-art / (C) «In Kyiv» (in Russian).

13. http://vkieve.net/street-art/ikony-revolyucii-na-grushevskogo

14. Interesting facts about the Ukrainian hut TOP-10. / IRPIN TODAY. News of Irpin, Buchy, Vorzel, Gostomel, Kotsyubinsky / - Jan 22, 2017.http://irpin.today/?p=5445

15. Irina Ginzhul. Puzzles and stories of the Kiev mosaic: «To wake stars and sickles on mosaics were forced»/SEGODNYA. Lifestyle - September 19, 2015, 09:30. (in Russian).

16. https://www.segodnya.ua/lifestyle/fun/zagadki-i-istorii-kievskih-mozaik-lepit-zvezdy-i-serpy-na-mozaikahvynuzhdali-649239.html

17. Lyudmila Knyazhskaya-Khanova. PHOTOFACT. In Kiev, created an amazing murale icon. / SEGODNYA. Lifestyle - September 21, 2015, 13:26. (in Russian).

18. https://kiev.segodnya.ua/kpeople/v-kieve-sozdali-udivitelnyy-mural-ikonu-651334.html

19. Mitya Raevsky. Trypillian culture: Who were and how our distant ancestors lived. / ZNAJ.UA. - 23.06 19:33 (in Ukrainian).

20. https://znaj.ua/trypilska-kultura-kym-buly-i-yak-zhyly-nashi-daleki-predky

21. Mural at the police building in Kyiv got the world's best in the month (video) - 20:30, November 30, 2017 , SOCIETY (in Ukrainian).

22. https://www.unian.ua/society/2272659-mural-na-budivli-politsiji-u-kievi-potrapiv-u-svitoviy-reytingnaykraschih-za-misyats-video.html

23. Mural «Vozrozhdenie» on the Andreevsky Descent. Street-art / (C) «In Kyiv» (in Russian).

24. http://vkieve.net/street-art/mural-vozrozhdenie

25. Mural with the Blessed Virgin Street art. Street-art / (C) «In Kyiv» (in Russian).

26. http://vkieve.net/street-art/mural-s-presvyatoj-bogorodicej

27. Sophia of Kyiv. Reserve St. Sophia Cathedral in Kiev. ST. SOPHIA CATHEDRAL. Mosaic and frescoes of Sofia Cathedral. (in Ukrainian).

28. http://sofiyskiy-sobor.polnaya.info/ua/sofiivskiy_sobor_mozaiky_i_fresky.shtml

29. Tetyana Kochubinskaya, art critic, specially for «UP.Zhitiya».The most interesting Kiev mosaics of the 60's. PHOTOS. 23.04.2015, 14:01. (in Ukrainian).

30. https://kiev.pravda.com.ua/publications/5538d11763f46/

31. The folk architecture of the ancient Ukrainian village. / ETHNOCHAT. (in Ukrainian).

32. https://etnoxata.com.ua/statti/traditsiji/narodna-arhitektura-starodavnogo-ukrajinskogo-sela-abooblashtuvannja-zhitla-nashimi-predkami-riznih-regioniv/

33. The disappearing layer of culture: mosaic panels of Soviet Ukraine / varjag2007su, Livejournal - 2018-0101 16:09 (in Ukrainian).https://varjag2007su.livejournal.com/1894366.html

34. Trypillian culture. / Symbols of spiritual evolution (in Ukrainian).

35. http://www.holysymbols.org.ua/ukr-home/83.html

36. V. Podnos, I. Verbytsky, I. Tischenko, M. Gryschenko, analysts of CEDOS. Murals - the embodiment of symbolic power to change the image of the city. / Culture, Public Space, September 19, 2016. (in Ukrainian).

37. https://mistosite.org.ua/ru/articles/muraly-vt\%D1\%96lennya-symvol\%D1\%96chnoyi-vlady-dlyazm\%D1\%96ny-obrazu-m\%D1\%96sta

38. Remains of a «scoop» on the walls or mosaics of Soviet Ukraine in the photo /24 Channel. E. Nikyforov. 22:59, February 18, 2016. (in Ukrainian).

39. https://24tv.ua/zalishki_sovka_na_stinah_abo_mozayiki_radyanskoyi_ukrayini_u_foto_n659651

40. Samoilovich V.P. Ukrainian folk dwelling (the end of the nineteenth and early twentieth centuries). - K.: Naukova dumka, 1972. (in Ukrainian).

41. http://etnoua.info/novyny/knyha-ukrajnske-narodne-zhytlo-viktor-samojlovych/ 